\title{
Discursive exclusion and disrespect in prisons in Brazil
}

\author{
Carolina Barreto Lemos \\ Marcus Cardoso ${ }^{2}$ \\ 'Universidade Federal de Lavras, Departamento de Direito, Lavras/MG \\ ${ }^{2}$ Universidade Federal do Amapá, Programa de Pós-Graduação em Estudos da Fronteira, Macapá/AP
}

\begin{abstract}
In this paper, we present our ethnographic material and interpretations concerning the meanings that men and women imprisoned in the Federal District, Brazil attributed to their everyday experiences, with a special focus on the situations, statements and perceptions of these social actors related to that which we classify as structural processes of discursive exclusion. Drawing from our field data, we argue that these processes are a central dimension of pulling time, which not only configure a form of disrespect, but also the condition needed to sustain a structural scenario of violence and violation of rights in these prisons. In addition, the processes of discursive exclusion are essential to understand how the experiences of disrespect were interpreted and addressed by the interlocutors. The data presented are the result of ethnographic research carried out between 2014 and 2018 with men and women imprisoned the Federal District, Brazil.
\end{abstract}

Keywords: discursive exclusion, disrespect, prisons. 


\section{Exclusão discursiva e desconsideração em cadeias no Brasil}

\section{Resumo}

Neste artigo, apresentamos o material etnográfico e nossas interpretações acerca dos significados que as pessoas em situação de privação de liberdade no Distrito Federal davam a suas experiências cotidianas, com especial foco nas situações, relatos e percepções desses atores sociais relacionados àquilo que classificamos como processos estruturais de exclusão discursiva no âmbito desse contexto. A partir de nossos dados de campo, sustentamos que estes processos são uma dimensão central do puxar pena, não apenas configurando uma forma em si de desconsideração, como também a própria condição necessária para a manutenção de um quadro estrutural de violência e violações a direitos no cárcere. Além disso, os processos de exclusão discursiva são fundamentais para a compreensão do modo como a experiência de desconsideração era interpretada e elaborada pelos/as interlocutores/as. Os dados apresentados são o resultado de uma pesquisa de campo, realizada entre os anos 2014 e 2018, com mulheres e homens que cumpriam pena no Distrito Federal.

Palavras-chave: exclusão discursiva desconsideração, prisões. 


\title{
Discursive exclusion and disrespect in prisons in Brazil
}

\author{
Carolina Barreto Lemos
}

Marcus Cardoso

More than thirty years since Brazil's political redemocratization process began, the civil components of citizenship ${ }^{1}$ continue to be systematically violated by institutional practices that directly conflict with the fundamental principles of a rule of law. In the realm of criminal justice, for example, empiric studies reveal that this reality is revived daily in all its dimensions, ranging from the truculence of police practices to arbitrary and discriminatory standards that characterize the action of the Public Ministry ${ }^{2}$ and the courts in general (Fórum Brasileiro de Segurança Pública 2019; Alves 2010; Caldeira \& Holston 1999; Cardoso 2005, 2012, 2013; Misse 2010; Medeiros 2019; Kant de Lima 2003; Schritzmeyer 2019; Sinhoretto 2015; Muniz 2018). This situation led Holston and Caldeira to classify Brazil as a "disjunctive democracy" (Caldeira \& Holston 1999; Caldeira 2000; Holston 2008), an expression applied to emerging democracies that have relatively healthy electoral systems, but whose formal institutions for social control are unable to universally assure the civil rights of their citizens. In the context of the prison system, studies have shown that this situation of rights violations is particularly grave and marked by systematic standards of torture and poor treatment, a reality observed in different states of the country, such as Rio Grande do Norte (Melo \& Rodrigues 2017), the Distrito Federal (Lemos 2017b, 2019a, 2019b; Melo 2016), Rio de Janeiro (Andrade \& Geraldo 2020), Rio Grande do Sul (Bogo 2006), Maranhão (Silva 2019); São Paulo (Biondi 2009; Higa \& Alvarez 2019), and in reports of national entities about torture in the prison system (Brasil 2009; Brasil 2020; CNBB 2018). These practices provoke feelings of humiliation, injustice and indignation among the individuals and social groups who are the preferential victims of these arbitrary acts - most of whom are from black and or poor communities. These feelings are often articulated through their own local grammars (Cardoso 2014a, 2014b; Lemos 2017a; Lemos \& Cardoso 2020).

Inspired by the contributions of researchers who work within the spectrum of the anthropology of law and who defend the need to give special attention to notions of justice and rights developed by concrete social actors and that are circumscribed in specific contexts - in Brazil, Cardoso de Oliveira (2011a), Kant de Lima (2003), Schritzmeyer (2019) and Fonseca (2011), and, internationally, Geertz (1998), Nader (1997) and Lazar (2008) - in this article we present ethnographic material and our interpretations about the meanings that people in a situation of deprivation of liberty in the Federal District give to their daily experiences, with a special focus on the situations, statements and perceptions of these social actors related to that which we classify as structural processes of discursive exclusion.

One of the aspects that caught our attention during the study is that the social protests formulated by these actors rarely are expressed through positive terms, but by means of reports of experiences of injustice that reveal particular expectations of justice and moralities, similar to that which Honneth (2007:350) would call "intuitive" [or native] notions of justice. Therefore, it is essential to pay attention to the symbolic meanings of the perceptions of social actors in contexts of social vulnerability marked mainly by poverty and difficult access to rights, as highlighted by Cardoso (2014a, 2014b) and Cardoso de Oliveira (2011a).

1 For Caldeira and Holston (1999) civil components refer to the sphere of rights, practices and values that concern positive and negative liberty, and to justice as a means for assuring all rights.

2 As federal and state prosecutors offices are known in Brazil. 
One fundamental aspect of the narratives of experiences of injustice in this ethnographic field is the importance attributed by interlocutors to the quality of the social bond in the context of pulling times. Thus, they frequently experience the violent practices in prisons, which may or may not imply the violation of positive rights, as an attack on the fundamental dimensions of their personal integrity (Lemos 2017a; Lemos \& Cardoso 2020). The importance of the interpersonal dimension of rights in this ethnographic universe, marked by expectations for respect and dignified treatment, led us to characterize this scenario as a radical experience of disrespect (Lemos 2019b), which implies a systematic attack on the three dimensions of social recognition, as formulated by Honneth (2007).

With this in mind, in this article we are fundamentally interested in the way that this radical experience of disrespect is intertwined to that which we classify as structural processes of discursive exclusion. These processes take place both by a denial of access to the material and symbolic instruments required for incarcerated people to articulate and publicize their dissatisfactions and claims, and by the disqualification of their speech or retaliation against these subjects when they find legitimate means, even if clandestine ones, to do so, which prevents them from being effectively heard. Based on our ethnographic material, we sought to demonstrate that these processes are a central dimension of pulling time, configuring not only a form of disrespect, but also the very condition needed to maintain a structural framework of violence and violations of rights in prison. Moreover, the discursive exclusion processes are essential to understanding how interlocutors interpreted and formulated this radical experience of disrespect.

The data presented in this article are the result of a field research conducted between 2014 and 2018, with men and women completing serving sentences in the Federal District. According to data from SISDEPEN (2020), the Federal District had 15,09o people jailed, including 721 women and 15,327 men. The district has 8 prisons, with a total capacity for 8,927 , which means an average occupancy rate of $169 \%$. The fieldwork was conducted at 4 of the prisons: the Female Penitentiary of the Federal District (Colmeia), the Penitentiary of the Federal District I and II (Cascavel), the Provisional Detention Center (CDP) and the Centre of Penitentiary Progression, known as Galpão. Twenty-nine people incarcerated in the capital were interviewed, including 12 women and $10 \mathrm{men}$. The interviews were in-depth, lasting from 60 to 120 minutes, and were not structured, they did not follow a predefined script. All were conducted in privacy and recorded in audio. In addition to the interviews, the data presented also refer to observations made during the field trips and informal conversations with prison employees and imprisoned people, always maintaining anonymity (Lemos 2017b).

In the first section of this article, we analyze situations and narratives that reveal structural processes of that which we classify as the discursive exclusion of imprisoned people. Then, to support the analysis of their narratives and situations experienced in the field, we explore the factors that determine the dissatisfaction of the interlocutors with forms of treatment in the local prisons. In the third section, we deepen the analysis of the articulations between the structural processes of discursive exclusion and the broader situation that characterizes a radical experience of disrespect in this ethnographic field.

3 Italics are used to indicate a native category or statement. Puxar pena [to pull time] transcends the legal concept of "cumprir pena" [to serve time]; it encompasses the totality of the experience of incarceration, whose multiple dimensions cannot be reduced to a formal legal concept, given that they involve a wide variety of aspects that are constitutive of human experience and socialization. 


\section{Discursive exclusion in the prisons of the Distrito Federal}

In this section, we highlight situations and narratives that reveal structural processes of that which we classify as discursive exclusion of incarcerated people. We believe that this is an important aspect of any study that wants to understand and analyze the Brazilian prison context based on the perspective of the imprisoned people. As we demonstrate throughout the article, it is linked to a broader phenomenon of institutional processes of disrespect of the identity and dignity of people deprived of liberty, which are marked by forms of treatment that violate their formal rights and reduce their social value and esteem, and is fundamental to the configuration and maintenance of this situation. In the prison context of the Federal District, it was possible to observe these processes of discursive exclusion in two ways: a) by institutional strategies that deprive or restrict the access of imprisoned citizens to the instruments needed for them to articulate and or publicize their experiences of social injustice; and b) by treating them as inferiors and consequently disqualifying the discourse of these citizens, or by retaliating against them when they found legitimate means to communicate their perceptions of injustice, which does not permit them to be effectively heard. For purposes of clarity, we analyzed separately what these strategies are and how they are implemented and experienced by the interlocutors.

\section{Denial of access to information and means of communication}

The institutional processes aimed at preventing or obstructing imprisoned people from formulating or manifesting perceptions of social injustice were deeply capillarized in the prison units of the Federal District and appeared in different ways. Fundamentally, these mechanisms consisted in forms of restricting the imprisoned people's access to the material, symbolic and linguistic means necessary to articulate and or publicize their perceptions of injustice and demands for rights. These institutional procedures made communication by prisoners difficult within and beyond the prisons; they impeded the access of these citizens to information; restricted their opportunity to become aware of their formal rights; and obstructed or made impossible their attempts to engage with agencies that act in the protection of human rights in prisons, issues that frequently appeared during the field research.

Luís was one of the interlocutors who best conceptualized and systematized this issue in the field, bringing to light the different institutional strategies by means of which this discursive exclusion was implemented in the prison routines. Luís' experience in the prison system of the capital began more than a decade earlier, when he was placed under preventive arrest in the CDP, where he remained for 3 years and 7 months awaiting his sentence, and then pulled time in Cascavel. In 2014, when we met, Luís was sentenced under house arrest ${ }^{4}$ and worked at the National Penitentiary Department under an agreement with the Foundation for the Support of Imprisoned Workers (Funap).

He felt highly frustrated with a lack of access to education within the prison system, not only because of the difficulty he faced finding an opening in the school at the Cascavel prison, but also because of broader restrictions to access to information. For example, he highlighted institutional impediments to the entrance of letters, books, newspapers, and magazines in the prisons:

There was a time there, I don't know if it's still like that, but you don't get letters and letters don't go out. That is, they completely violate the LEP, because we didn't even have access to a bible, not even a bible got in. You don't have access to a printed newspaper or to a magazine. If our family enters with a book, even if it's from school, like when I did the ENEM [a college entrance exam] in there, I asked my mother to take me a book to study. My mother paid a lot for a text, when she got there, they wouldn't let it in. The LEP states that we all have the right to information, to read, right?

4 Brazil adopts a progressive punishment system, divided in three stages: closed, semi-open and open, as stated in Art. 112 of the Lei de Execuções Penais [Criminal Sentencing Law - LEP]. In the Federal District, the "open regime" is served under house arrest. 
Well, there we don't have this right, they violate all the rights that we have. [...] You begin to have [ the option to have] a television when you are convicted and go to prison, then they allow your family to take you a television, but meanwhile...It's the same, I stayed 3 years and 7 months without being able to watch television, so imagine spending 24 hours a day staring at a wall, you can't read a bible because they don't let bibles enter, you can't read a newspaper because they don't let you have a newspaper, understand? You are totally isolated from the world, it seems that you were thrown inside a hole and forgotten there, you don't know about your case, you don't know how your life is outside, if your family doesn't come one month, you don't know how your family is, understand?

In the Federal District, communication by imprisoned people beyond the prisons was done with letters and visits, the latter being the most important way to maintain social ties and contact with the street. When sending and receiving letters was permitted in the prisons, they were censored by the institution before entering or leaving. Even if the institutional censorship was justified as a security measure - to prevent, for example, that imprisoned people maintain illicit activities outside the institution - the interlocutors affirmed that this control over the content of letters was also used so that they could not denounce situations of torture or other rights violations. Moreover, the institutional procedures to inspect the content of letters considerably delayed their sending, which made it impossible to have an efficient response if the letter involved an urgent problem or need, like a request for family to send medications or other products.

The visits at the prison units were considered sacred by the interlocutors and were weekly for people who had been sentenced and biweekly for those awaiting sentencing. In addition to the affective aspect of maintenance of social ties, they exercised important functions in the life of the incarcerated, such as the supply of the cobal, which is the name given to a package of supplies taken by family members with food, toiletries, clothes, medicine, cigarettes, and other items ${ }^{5}$. Each unit had a list of materials that could be received, which were carefully inspected when the families entered. As Luís observed, books and other reading materials were items whose entrance were frequently impeded or prohibited. Among the most accepted books, the interlocutors always mentioned the bible. There was even a strategy to get around controls over reading content by hiding other books behind the cover of a bible. The interlocutors said that the items least tolerated were law books, manuals, codes and references books.

Luís believed that this censorship about reading materials, especially legal texts, was to deny the imprisoned person the knowledge needed to be aware of and demand rights. In this context, Luís linked the lack of greater opportunities to study in the penitentiary system with the lack of interest by the state in instructing or educating imprisoned people:

I did not have the opportunity to study. I wanted to, but I couldn't study because that was for the privileged ones. So I think there should be a greater effort in relation to this. [...] I think that they should build a quality school inside the prison, because there is room for this, understand? There are resources for this. But it's like, they're not interested. I think that for them, in their opinion, the dumber the inmate is, the better it is for them, right? Because I think that from the moment that the inmate begins to understand his rights, it makes it difficult for them. So I think that for them the more the inmate is uninformed, the better. It can only be this. The state does not make the effort to imprison and turn out citizens.

Luís' reflection reveals the perception that the reasons behind the institutional strategy to deprive access to information was to avoid that inmates could raise awareness about their rights, because, if they had a more articulated consciousness of them, it would make it difficult for the prison institution. The limitation or obstruction of access to manuals and texts from the field of law and the lack of interest in a broad educational policy in prison, which were issues raised by various interlocutors, concretely interfered with their opportunity

5 In general, the prison establishments in Brazil do not provide sufficient means of livelihood. 
to inform themselves about their formal rights (and, therefore, about the violation of them), to articulate their experiences of injustice with a grammar that is considered valid and appropriate in the legal context, and to seek legal means to denounce violations and to demand the concretization of these rights.

In addition to the cobal, it was common for family members to take to their imprisoned relatives papers (usually printed versions of documents found on the internet) with information about the progress of their criminal case, their situation in the sentencing process, the procedural deadlines for the progression of their punishment regime, etc. These papers were also the object of censorship when visitors entered, which was one of the reasons for dissatisfaction among interlocutors:

You have no legal services, or accompaniment, so we turn to the family, and the family cannot enter with your case records, about your life, about the progress of your case, they don't allow it. (Luís)

For Rafael - who spent 10 years and 5 months imprisoned in Cascavel - the obstacles to entrance of legal texts and of information about the case proceedings had the objective of preventing them from knowing their rights and formulating legal requests, like requests for progression of the punishment regime. He explained that, when they had these tools, many convicts began to write requests to the sentencing judge and some even charged for this service:

That's why, there inside, it's the same thing, sometimes there was a Penal Code or the Sentencing Law, it was nearly hidden depending on the block, so the person would hide it, put another cover on it. They put the cover of a bible on it. Because, for example, one of the reasons they did not want you to know your rights and also do not want to allow - because there are many people who make requests out of need, they learn how to make a request and [then] charge [others] ten reals to make a request, that's why.

He also said that, to have the requests reach the judge, this was also done clandestinely. The requests would be given to family members on visiting days for them to file. However, since many prison units also searched visitors upon leaving, even if hidden, the requests were frequently confiscated before they could leave the institution and their authors could be punished ${ }^{6}$ :

Normally, it goes through family, on their way out on visiting day. And you have to pray to God that the police' won't stop the person, and search them, because if they find someone leaving with a letter for a judge, they normally punish the person, cancel their visit, and send the person to isolation.

In relation to the possibility to communicate with the sentencing judge, Denise - who at the time of our conversation, in 2014, was, since mid-2013, pulling time in Colmeia - compared her experience there with that which she had in a prison in the state of Goiás years earlier. She said that, in Goiás, women inmates had regular contact with the sentencing judge, who would frequently go to the jail to speak with them, and she had a habit of sending the judge letters with her requests:

Super smooth, we worked it all out talking. [...] I would write letters to the judge, when it's like that you have this free will, because the judge of your jurisdiction himself goes, you sit at one of these tables, they get the inmates from his jurisdiction, 15, 20, 30 women, and then he speaks with them, shows your case and speaks with you. And it's like he gives you more, we are treated more human like that, humanely, right, it's not the same here. Here it's like we are the garbage of society right? People see us here with other eyes, they don't want to know who we were, why we did that, no one wants to know the reason, they just know that we are a bunch of bandidos [criminals], the same old discrimination, even though there are some here who have bad minds. I don't know, in Goiás we were always treated humanely, more humanely. [...]

6 This category refers to the various micropenalties that are applied in the prison context for noncompliance with disciplinary norms of the institution and that range from the temporary suspension of a right to the segregation of the inmate in an isolation cell for a given period of time (Lemos 2019a).

7 The interlocutors refered to the security guards in the prisons as police. 
[The judge] would ask what was happening, if there were any problems. I would make a whole report, of everything and would go explaining each item to him: one shift [of guards] did this, this is wrong.

It is particularly important to note that Denise interprets the possibility for regular contact with the judge and of resolving everything by talking as a more humane form of treatment, to the degree that, at Colmeia, she felt treated like the garbage of society, which she associated to a belittling of her identity through the stigma of bandido [criminal]. Moreover, her statement demonstrates that the regular contact with the judicial authority allowed effective control over the institutional practices that she considered to be wrong, allowing to seek the concretization of their expectations for more humane treatment.

Still in reference to the institutional practices aimed at preventing engagement with human rights agencies by the prisoners or their families, the experience of Francisco, who in 2015 was pulling time (in a semi-open regime) at the Galpão, is also illuminating. Before his definitive condemnation in the criminal suit, Francisco was held provisionally at CDP. During this time, he said that, once, when there was an invasion ${ }^{8}$ in his wing, he was hit in the stomach with shrapnel from a tear gas bomb. Because of his wound, the guards wanted to send him to isolation so that his family would not see his wound and file a complaint to the human rights ${ }^{9}$. He emphasized that this was a common procedure when someone was injured during these operations inside the prison: to place a person in isolation, a period during which they would not receive family visitors, so that they would not see the marks of the wounds and file a complaint to the agencies.

We emphasize the particularly coercive aspect of this institutional policy, characterized by the physical segregation of the person whose body carries marks of torture, in order to avoid that their support network (in this case family members) would be aware of the violation while there were still material vestiges of its occurrence.

\section{Disqualification and retaliation}

Another form of discursive exclusion of inmates observed in the field refers to the disqualification of their statements or retaliation against them by imposing punishments when they were able to publicize their demands. Thus, while the mechanisms emphasized in the previous item intervened to prevent or obstruct the expression of demands and complaints, those treated in this section were triggered after these (attempt at) expressions, in order to neutralize them.

Thus, discursive exclusion in this context took place not only by restricting inmates' access to the means needed to articulate and express their experiences of injustice and demands for rights, but also by applying reprisals against them when they find ways to do so. Cleonice, who in 2014 was pulling time in a closed regime in Colmeia, narrated an illustrative experience in this respect. She said that during a visit of the human rights, she shouted that the food was arriving spoiled, but that: As soon as human rights turned its back, I was sent to isolation. For this reason, I never said anything again. In this case, even if the institutional strategies of discursive exclusion in this prison were not able to prevent Cleonice from expressing herself, the reprisal applied against her neutralized, to a certain degree, her behavior, coercing her to never say anything again.

Luciano's statement is quite illustrative of this. In 2015, Luciano, who had already undergone provisory detention at CDP and a closed regime at Cascavel, was pulling time in a semi-open regime at Galpão, and working in the central archives of the Ministry of Justice, by means of an agreement with the FUNAP. Referring to the period when he was jailed at Cascavel, he spoke about the frustrated attempts to denounce abuses at this prison:

8 Search operations conducted by the police in the wings and cells.

9 Interlocutors frequently used the term human rights to refer to people from human rights agencies, who visited the prison units, instead of to a set of universal abstract rights, as discussed in Lemos (2019b). 
If we make a complaint inside, anything, they take our name, they transfer the guy to the worst block, each time the guy passes through they go over him, they constantly humiliate him. And if we sign any paper, many times when they passed petitions with a list of complaints, I didn't sign it, because I have seen many people harmed just because they signed a petition denouncing the injustices inside.

Luciano highlighted a form of denunciation mentioned repeatedly by the interlocutors, a petition, although there was only one report of success with this strategy ${ }^{10}$. Most of the reports about this initiative are similar to that of Luciano, resulting in the retaliation against those who signed the document. We can also note here coercion by means of punishment as a form of neutralizing denunciations of injustice. The punishment mentioned in this case did not take place by means of isolation of the prisoner, but of his transfer to the worst block ${ }^{11}$ and by repeated searches (known as a going over) and practices he considered humiliation. Thus, he affirmed that he did not get involved in these initiatives, for fear of being harmed.

In Colmeia, the notion that the inmates lie was repeated several times by the prison officers. Beatriz's case illustrates this. In 2015, Beatriz did time at Colmeia in a closed regime. At one of our meetings, she expressed tremendous dissatisfaction because she had gone more than 8 months without work at the prison, which meant that she did not have the opportunity to reduce her sentence ${ }^{12}$. She was previously working at the beauty parlor, but had been declassified ${ }^{13}$ with no formal justification. In fact, when she consulted the Disciplinary Center at Colmeia, the researcher found that there was no record of any disciplinary problem that would cause the loss of her work post. The prison employee who supervised the work in the workshops, when questioned by the researcher about the reason for the declassification, did not make a point of providing a formal justification and said: They give their version of the story, they want to play the victim.

This phenomenon was even more evident in a situation witnessed with another interlocutor in the field, Gustavo, who in 2015 was serving time in an open regime, which meant that he was under house arrest. Before this, he had spent more than 5 years imprisoned under a closed regime, first at the CDP and later at Cascavel. Since our first meeting, Gustavo expressed his desire to appear at a public arena for discussion, preferentially a law school, to share his experience in local prisons. The opportunity wound up arising a few months later when he was invited to participate in a round table about prison violence that was part of an event organized by a law school. Gustavo promptly accepted the invitation. The roundtable was composed of Gustavo, three researchers and a professional from the field of human rights who also had been through the prison system in the Federal District. Gustavo asked to be the last to speak. A few moments before his talk, he noticed someone entering the auditorium. He signaled to the researcher who was in the audience to come to the stage. She asked what was happening and he said: You see that person who just walked in? I know him, he's a security professional at Cascavel. Asked if he wanted to leave the table, he said no, that he wanted to speak.

Although he insisted on staying, he was clearly tense during the talk. Finally, when the discussion was open to questions from the public, the security professional was the first to ask to speak. He spoke for about 10 minutes. He expressed resentment with statements made in the talks, emphasized the difficulty of his work, and said a few times that lies were being told. Other interventions from the public were made. When time came for the speakers to respond to the questions, the security guard once again tried to speak, and once again insisted that Gustavo's statements were not honest. In response, Gustavo spoke with more confidence: he told his story and responded to the insinuations. At the end of the event, he went to the professional and said: You know that what I said is true.

\footnotetext{
10 Helena said that when they would not let shampoo enter in Colmeia, the women signed a petition, against the measure and it was reversed.

11 The worst block referred to the blocks where there was less access to a work post or study and where there were more invasions by guards.

12 The redemption of a sentence for time worked is determined by LEP (Art. 126 a 130). It allows an inmate to redeem one day of imprisonment for every three days worked.

13 To be declassified meant to lose a work post at the prison.
} 
Thus, during the fieldwork it was possible to observe an important dispute of narratives in the local prisons, based on a systematic disqualification of the speech of the imprisoned interlocutors. In the context of these regimes of truth, the use of the category public faith ${ }^{14}$ was an important way of differentiating the value of discourses offered by inmates and by people who work in the prison system. Pubic faith implied that these professionals deserved a type of presumption of honesty, and was conceived not only as a public testament of the authenticity of documents issued by court officials, but as an immanent quality of the subjects themselves who occupied these public positions.

This peculiar formulation of public faith was quite evident in a situation that the researcher experienced in the field. In mid 2015, nearly 8 months after the interviews were completed at Colmeia with women who pulled time in a closed regime, she returned to the prison institution. This time, she was there because of the imprisonment of Helena, an interlocutor who she had met months earlier at the National Penitentiary Department, where Helena worked under an agreement with the FUNAP. At the time of the first meeting, Helena was pulling time in an open regime and was under house arrest. A bit later, Helena was detained again and sent to Colmeia while awaiting trial. In this period, after contacting Helena by letter, the researcher tried to visit her in the prison. Although prison administration had authorized her registry as a visitor, at the time of the visit, when she waited outside to enter, she was called to the prison administrative offices and told she could not enter to visit. In a very hostile interaction with the employees, the justification given was that, given that the she had done research there a year earlier, she could not be a visitor at the unit (although there is no legal or formal prevision about this, so much so that her visit had been authorized in advance).

The following week, the researcher returned to the prison and was able to speak about what happened with Susana, an interlocutor who was an employee at the prison. Susana was very disturbed with the situation, which was embarrassing for her, considering that the researcher had spoken at length with her about her intention to register as a visitor and no question had arose about any reason why should could not do so. This situation was embarrassing to Susana because the attempt to visit created a problem for the prison administration - which made efforts to stop it, which Susana had not expected.

At one point in the heated discussion, Susana, who was quite nervous, presented her narrative about what had happened on the day the visit was prohibited. She was not there on that day, so her account was based on what she had heard from her work colleagues. Various accusations were made against the researcher, and when she challenged them and presented her interpretation about what happened, Susana responded that she trusted the version of her colleagues, firstly because she knew their character, and secondly, because a civil servant had public faith. It is interesting to note the strong moral content triggered in this regime of truth, which was present in Susana's affirmation that she trusted her colleagues because she knew their character. What was implied in this affirmation was that, to the contrary, either she did not sufficiently know the character of the researcher, or she had a negative evaluation of her character, which would make the researcher less worthy of trust than the civil servants. Thus, the validity of the discourse was linked to moral evaluations about the person who stated it.

Susana's response also demonstrated very well how the notion of public faith implied a presumption of truth for prison officers. She did not present herself impartially in responding to statements about a situation that she did not witness, but a priori positioned herself in favor of the institutional version, which would consist in a discourse that legitimates the exercise of power that had invoked unwritten and casuistic rules to justify prohibiting the researcher from being a visitor. This immanent quality of the civil servants does not only imply that their discourse is more highly valued, but that it had a status of presumption of truth. Given the public faith with which her colleagues were imbued, the word of the researcher had little or no value.

14 About public faith see Kant de Lima (2013). 
Thus, the triggering of the notion of public faith in this context created a situation in which the statements of imprisoned people - whose identities and moral value were repeatedly belittled - were systematically placed under suspicion, while that of the public agents enjoyed the presumption of truth, considerably reducing the possibility that the prisoners would be properly heard even when they found legitimate means to publicize their dissatisfactions and demands. If public faith was understood as an immanent quality of the subjects, due to the position that they occupied, the discursive disqualification of the inmates was also linked to the social status that they occupied and to their disqualification in the realm of citizenship.

\section{Forms of treatment in prisons}

All the interlocutors who were serving sentences during the fieldwork had a negative evaluation of the forms of treatment in the prisons of the Federal District. In this section, supported by the analysis of their narratives and the situations experienced in the field, we explore the factors that determine this dissatisfaction. To do so, we first highlight which institutional practices were most questioned by the interlocutors and then analyze the main reasons for this dissatisfaction.

As we saw, these social actors frequently experienced these procedures as forms of humiliation and embarrassment that violated expectations of respect and decent treatment and demeaned their moral value and social esteem. Our intention here is to show how the forms of discursive exclusion discussed in the previous section were linked to a broader scenario of experiences of disrespect that violated the interlocutors' normative expectations of respectful treatment and restricted their opportunities to articulate or publicize their perceptions of injustice. It is interesting to note that demands for dignified treatment were rarely expressed in the form of positive and abstract claims but through reports of experiences in which these expectations had been violated. We believe that this difficulty to formulate positive demands is associated to the processes of discursive exclusion, which prevented access to the symbolic and linguistic means needed to elaborate them.

The passages presented in this section represent different dimensions of pulling time: they refer either to institutional procedures, or to relations between guards and prisoners, or to material living conditions in the prisons. These social actors frequently experienced these different aspects as aggressions, which we classify in this article as forms of disrespect, which offended their personal integrity and sense of dignity.

One of the critical issues were the conditions of hygiene, accommodation and nutrition in the prisons of the Federal District. In general, the interlocutors considered them terrible in all the prisons, but were particularly tragic in the places of pre-trial detention and in closed regimes, for both women and men. In these environments, which did not have proper ventilation and lighting, the cells were stuffy and hot in summer and cold, damp and moldy in winter. The showers were simply a cold-water pipe located above the latrine, known as the boi [literally an ox], located on the floor in the back of the cell, with no flushing mechanism or seat. The jegas (bunks), were made of concrete, with a thin mattress above. Since the number of people in the cells in the wings for pre-trial detention and closed regimes could be three times the number of available bunks, some of the residents slept on the beach (floor). Cleonice, for example, reported that, when she was in the wing for provisory detention at Colmeia, she slept inside the boi because of a lack of space: Yeah, we would get a black plastic bag, a blanket, cover the hole in the toilet, wash the wall, and put down the mattress to sleep inside. It was very crowded.

The food served in the prisons, which was supplied by outsourced companies, was another factor that frequently generated discontent. The interlocutors repeatedly accused the supplier of the xepa (the container in which their meals arrived) with carelessness, and affirmed that the food often arrived raw, spoiled or rancid. Helena, one of our interlocutors, who had spent nearly two years jailed at Colmeia, claimed that the food served there could not even be served to animals: It's the worst xepa, I don't think that even a pig 
would eat that xepa. Combined with the lack of care with the quality of the food, complaints from the inmates and requests to switch a dish when it arrived spoiled were often retaliated by the police by sending those who complained to isolation, for inciting the mass ${ }^{15}$ to protest or rebel. In this sense, Luciano reported his experience at Cascavel:

I have seen the entire cell complain about the xepa, show the xepa to the police, to the shift, then an assistant comes to smell it, and say "this tray is not bitter, inmate". Then he takes everyone's tray and notes the name, then everyone gives their name, thinking that they will receive another warm one...Then the next day everyone was punished, they said they caused a riot, incited the mass, I don't know...

Another form of treatment that generated discontent was how the guards referred to or called the interlocutors in jail, which varied between the most complete impersonal quality, to insults and cursing. Luís, for example, complained of impersonal treatment - as prisoner or inmate - and recalled that being called by name was a right of incarcerated people in Brazil, which is even guaranteed by law ${ }^{16}$. Moreover, there were many complaints about insults. The statements below, by Helena and Francisco, indicate this:

We get upset inside, even more so when the guards insult us "disgusting", "pig", "you'll never be another person when you get out". (Helena).

You have to see the torment, they called us dirty and all kinds of names. Cursing and putting you down. (Francisco).

The lava-jato [car wash], the name given to the arrival procedure at the CDP, was also repeatedly mentioned as a very violent experience. This ritual of arrival consists in leading the naked prisoners to a small patio, under the commands shouted by the agents, to bathe quickly under cold water and then shave their hair and beards ${ }^{17}$ :

As soon as you enter, its poor treatment. On the first day that I got there, they put me in a cubicle with a latrine and shower, there were about three showers, not a shower just a normal spigot, they put the naked guys inside, stark naked, no underwear or nothing, and they shaved my head. From then on, you think 'dam, I'm going to stay naked with all these guys here?' Then they give you a tiny piece of soap, not soft soap, a bar of hard soap, for you to make due, to take a bath. Then they take it, then you get your clothes, put on your clothes, and go to the yard. Then everyone stays in the yard with hands on their head, sitting one behind the other, and they are yelling, oppressing, oppressing you. (Gustavo).

Narratives of systematic violence during the cell searches were also common among the interlocutors. Episodes characterized by the destruction of personal belongings and mattresses, and the discarding of food brought by family. Luís said that in the CDP these searches, which the interlocutors called invasions, were especially arbitrary and violent:

In the CDP, they enter kicking the door, throwing tear gas bombs, shooting a 12 gauge. Sometimes you are sleeping, and then a bomb explodes inside the gallery. Soon you just see them coming in with masks, all in black, cursing and telling you to stay in procedure. Then when you go to the yard, it's another problem, they take almost everything, when they enter your cell, what you have in your cell is garbage, then what's left in your cell is really garbage, when you get back, its empty, there's nothing left. Everything you bought ${ }^{18}$ goes to the garbage, there's nothing left. And at times they go in almost every day, every week, they've come in at three-four in the morning, everyone sleeping, and they invade.

\footnotetext{
15 The expression massa carcerária (prison mass) is used to refer to the population of prisoners in the establishment.

16 Art. 41, XI, LEP.

17 Hair and beard had to be shaved in the male prisons. For one of our interlocutors, noncompliance with this rule led to a punishment, with the loss of a job opening.

18 There was a canteen in this establishment, where inmates could buy food, cigarettes and other supplies.
} 
Another situation frequently mentioned by the interlocutors as especially difficult were the interventions in the sun yards when there were fights or other disturbances, which were episodes also marked by truculent action and excessive and arbitrary force, with the indiscriminate use of rubber bullets, pepper spray and stun bombs. About the interventions in the outdoor yard when there are fights among inmates, Helena said:

You're in the yard, and suddenly some girls begin to fight, then there's that tumult, to break it up, for the guards to see, they begin to shoot pepper spray. But the pepper spray is very strong, it gets everyone. And everyone must sit on the ground with hands on their heads for the guards to do the procedure. [...] Then they shoot until they separate. There are people who weren't even involved. Like a girl was hit in the breast and it ripped half her breast. The rubber bullet doesn't kill, right, but it rips a piece off where it hits. So it hit here in the girl's breast, hit another girl's arm here. But when there is a fight you have to run and go to a protected corner. You have to hide so they don't get you, because they don't care, they shoot pepper spray and rubber bullets.

One important aspect in the narrative structures of the interlocutors is that at the heart of their protests we do not only find dissatisfaction with the disrespect for positive rights. What emerges from the protests is a type of dissatisfaction that relates to that which Cardoso de Oliveira (2011a) calls a moral dimension of rights, which transcends the violation of formal rights. After all, most of these criticisms were motivated by a violation of expectations of forms of treatment that they considered to be proper, a lack of consideration which was experienced as an offense to the physical and moral integrity of these people. The use of expressions such as humiliation, embarrassment and torment reveals that the experiences described stir feelings of moral depreciation and shame and the fact that these narratives were accompanied by expressions of pain, crying, silent pauses, exalted gestures and tones accentuated their dramatic nature for the interlocutors.

The dimension of the moral offense of these experiences became evident when we observed that the protests not only concerned attacks on the physical integrity of the interlocutors - such as the unhealthy conditions of accommodations or the use of tear gas bombs, clubs, rubber bullets and pepper spray - but also attacks on their moral integrity, by the exposure of their naked bodies, the destruction of personal objects, insults and cursing and lack of care about spoiled food. Whether they referred to attacks on their physical bodies or moral offenses, these practices directly affected important dimensions of the identity and dignity of the imprisoned people ${ }^{19}$.

These institutional procedures disturbed the sense of personal integrity in various ways: (i) by depriving them of a sense of privacy - by placing them in crowded cells with open and shared sanitary facilities; (ii) by depriving them of distinctive marks of their personality - name, appearance, possession of personal objects which were substituted by anonymous and deprecating elements, such as insults, the use of labels as prisoner or inmate, the imposition of ugly and poor quality uniform $\mathrm{s}^{20}$ and standardized haircuts; (iii) by exposing them to precarious hygiene conditions, which is verified by the unsanitary cells, the lack of suitable sanitation, the supply of spoiled and inadequate food: (iv) by collectivizing the authorship of their acts and respective punishments, as took place in moments of intervention in the yards. Their identity prior to incarceration was thus overshadowed, from an institutional perspective, by the stigma of prisoner. In the case of the interlocutors, it was clear that this overshadowing was perceived as embarrassing and signified as a form of oppression.

19 One dimension of this experience found resonance in what Lima (2001: 44) classified as "disarticulation of the personality of the inmate" when discussing the institutional procedures that accompanied the arrival to prisons in Brazil and in what Goffman (1974) called methods of "mortification of the self" in prison institutions.

20 The adoption of the uniform in Colmeia since 2014 was a recurring cause of dissatisfaction among the interlocutors, who felt degraded by its use. 
This phenomenon points to the process of attribution and incorporation of the identity of the prisoner in the prison context, which Foucault (1997) called "assujetissement" (subjection), and is experienced, although in different manners, by any individual submitted to a prison sentence ${ }^{21}$. In the cases presented in this article, these institutional procedures of disarticulation of identity and use of the label prisoner or inmate were similar to the process of social construction that Misse (2010) classified as "criminal subjection" and that were predominantly experienced by our interlocutors as a form of violence. In this sense, the narratives that point to efforts to separate their identity from these stigmas stand out:

In SENASP [referring to the time when he worked in the National Secretariat of Public Safety] it was also good [...]. Everyone respected me, no one treated me like a prisoner. Because there is nothing worse than always being remembered of your past, right? Even if indirectly. When you want to change and you constantly see the attitudes of these people, the people are trying to recall 'oh, you are different because you're a prisoner', and its embarrassing right? Not there, they treated me perfectly, they included me in everything [...]. So you feel valued, right? (Luís).

The expectations for attention to their moral value and social esteem are clear in the claims by these people to have their identity recognized beyond the stigma of criminal and prisoner. The lack of observance of this demand was experienced and called humiliation. This was the case, for example, of Cleonice, who told us that she felt depreciated in prison because of how she was treated: Because here inside we are treated very badly by the guards, not by all of them, but here we feel belittled, here you lose your value. Thus, the interlocutors repeatedly associated these social labels to deprecating categories, such as garbage of society, animal, dog, that frequently appeared in contrast to human and people. Interlocutors thus identified this phenomenon as a process of denial or relativization of their status as human and people, categories that concern not only their biological characteristics, but, mainly, the moral dimension of their identity. The statements by Aline - who spent 9 years imprisoned in a closed regime at Colmeia - and Denise are illustrative of this:

Ah I don't know, very ... inhuman. Very inhuman. [...] They wanted to treat us like garbage, like animals, like the scraps of the scraps of society. You know, whether you want to or not, you're kept there like the rest, the garbage of society, excluded from everything and everyone (Aline).

The people who work on the other side [prison guards] think that we are not human because we are here inside. [...] They think that, because we are prisoners, we have to do what they want and all, and we are not human, as if we couldn't feel tired or feel pain. (Denise).

Freire (2010) refers to a "regime of dehumanization" in her studies about the patterns of sociability in Rio de Janeiro, which allows the very status of "human being" to be socially questioned, through means of moral operations that "seem to create a consensus in relation to the idea that not everyone is worthy of being incorporated to common humanity" (Idem.: 128). Mbembe (2014) also examines the phenomenon of dehumanization when analyzing the racial discourses raised in countries of European colonization in the American and African continents in the nineteenth century. He emphasizes that, in the debate about whether a universal humanity exists, the idea that there is a "fundamental difference" between White people and Black and Indigenous people had repercussions, which led to the exclusion of Blacks and Indigenous from the "sphere of total human citizenship" (Ibid.: 157). Our ethnographic material from the prisons in the Federal District also reveal a "regime of dehumanization" - marked by forms of treatment that relativized the status of incarcerated women and men as human and people and denied them the moral substance of dignified people (Cardoso de Oliveira 2011a).

21 The stigma of prisoner, similar to the category bandido [criminal], can acquire different meanings in different contexts, as is the case of São Paulo (Biondi 2009). 
In this context, it is important to perceive that the meaning of human in this ethnographic field goes beyond the biological concept - understood as a quality shared by the entire human species - even if we cannot completely dissociate the physical dimension of existence from moral one in the experiences of the concrete individuals. Human is formulated here as an intersubjective social category that concerns not only the biological characteristics of a person, but also the social construction concerning their moral value.

In this context, the institutional processes of discursive exclusion of imprisoned people, analyzed above, constitute a fundamental dimension of the experience of disrespect that is intrinsic to pulling time. Similarly to the other forms of treatment that were object of dissatisfaction among the interlocutors, the inferiorization of their identity and dignity in the realm of citizenship established the foundation of their discursive exclusion (Cardoso de Oliveira 2011a; 2011b). Moreover, the rigid control of the discourse of imprisoned people was an important mechanism for the perpetuation of this situation of oppression and systematic violation of rights.

\section{Discursive exclusion and disrespect}

The structural processes of discursive exclusion in the prisons of the Federal District - characterized by restricted access to the means required for incarcerated people to formulate and express their dissatisfaction, and the depreciation of the credibility of their statements, or the retaliation against them, when they did so - constitute a central element of a broader situation that we call a radical experience of disrespect. These processes not only configure another form of disrespect, but also the means required for the maintenance and reproduction of the structural framework of violence and violations of rights in prison. In addition, processes of discursive exclusion are also fundamental to understand how the interlocutors interpreted and elaborated this radical experience of disrespect.

Cardoso de Oliveira (2011b) presents the notion of discursive exclusion in the preface of the book "Dimensões da violência: conhecimento, subjetividade e sofrimento psíquico" [Dimensions of violence: knowledge, subjectivity and psychic suffering]. In this text, Cardoso de Oliveira locates this notion in the realm of his studies about the association between experiences of violence and moral insult and dilemmas of citizenship in Brazil. In this sense, he stresses the symbolic dimension of violence, highlighting that these situations necessarily involve a perception of insult and disrespect by the person who suffers this violence. Cardoso de Oliveira affirms that experiences of violence are always marked by an arbitrary imposition or an unacceptable suppression of a symbol, which is associated to the denial of the victim's dignity ${ }^{22}$. In Cardoso de Oliveira's understanding, in the Brazilian case, these situations are aggravated by practices that he characterizes as discursive exclusion, an expression used to mark the difficulty of our state and public institutions to properly (substantively) hear citizens. In this sense, discursive exclusion would be a facet of the experience of moral insult, especially at its interface with the state, considering its difficulty in giving proper attention to the symbolic dimension of violence.

Unlike the conformation presented by Cardoso de Oliveira (2011b), in which discursive exclusion arises as one of the aspects that compose an experience of moral insult, in the context of prison establishments, this phenomenon is central, both to the experience of pulling time, and to the maintenance of a scenario of structural violence and violations of rights. Moreover, we believe it is important to highlight that, while Cardoso de Oliveira characterizes discursive exclusion as a difficulty of the state to substantively hear citizens, our ethnographic material points to a much broader and deeper phenomenon, which is characterized by the implementation of capillarized mechanisms designed to prevent or retaliate to the manifestation of demands

22 Cardoso de Oliveira associates this aspect to Habermas' (1970) reflections about "processes of systematically distorted communication". 
and dissatisfactions by imprisoned people. In this sense, it does not only involve a difficulty in hearing them substantively, but a deliberate policy of silencing them and establishing their incommunicability by means of coercive practices.

On the one hand, the discursive exclusion of people deprived of liberty is in and of itself an experience of disrespect intrinsic to incarceration. Similar to other forms of treatment that caused dissatisfaction among the interlocutors, institutional processes that silenced their voices were associated to perceptions of a denial of their identity and dignity and relativization of their humanity, through the imposition of the stigma of prisoner, as revealed by the statements of Luís and Denise above. On the other hand, the various cases presented in the article reveal a deliberate policy of silencing, in which we identify institutional strategies designed to cover up violence, impeding these people from accessing legal agencies or even their support networks (family and friends) or retaliating against them when they did so. These strategies also involved suppressing symbolic and linguistic instruments that are essential to the elaboration and expression of claims and denunciations, denying incarcerated people's access to information and to legal texts. In our understanding, these mechanisms are necessary to the maintenance of institutional practices that directly contradict individual rights and guarantees of imprisoned people established by Brazilian laws. In this sense, Luís emphasized the importance of obstructing communication with legal and protective agencies in order to allow the continuance of systematic violations of their rights in this context:

They know that the prisoner is vulnerable and has no voice. Because the prisoner has no voice, you understand? Because to whom will they shout out there? To four walls. They do not have access to a judge or to a prosecutor; they often don't even have access to a lawyer. So they have no one to turn to in order to seek their rights. And often if they try to do so, the guards will find out and will try to stop them.

Honneth's (2007) discussion of structural processes of cultural exclusion also helps us to cast light on mechanisms of discursive exclusion of incarcerated people in the Federal District, even if there are important differences between the two phenomena. Honneth locates this phenomenon within his formulation about disrespect, a concept that he considers central to the understanding of experiences of injustice that afflict one or more of the dimensions of social recognition. For Honneth, one of the marks of the experience of disrespect is precisely the fact that it is often expressed by means of negative feelings, such as humiliation, anger and indignation. Moreover, he highlights that in their negative form these expressions of resentment can reveal "intuitive notions of justice" - or "inner-morality" (Honneth 2007: 84) - held by the subjects, especially in terms of their expectations for social recognition in interactions. Specifically in relation to those experiences of injustice that he qualifies as "class-specific" (Idem.: 87), Honneth understands that it is improbable that socially suppressed classes and strata formulate their moral claims in terms of a system of values that are positively guided by moral norms. Referring to reflections by Foucault (1996) about procedures to exclude discourse, Honneth attributed this difficulty to processes of cultural exclusion, marked by capillarized strategies of maintenance of cultural hegemony by dominant social classes, groups or ethnicities disseminated throughout society, from access to basic education to the mass media, which suppress the symbolic and linguistic means needed to translate these experiences of injustice into concrete demands.

Certainly, the racist and classist bias of criminal selectivity - in Brazil and the Federal District - allow locating people deprived of liberty in the social groups and classes that suffer most from structural processes of cultural exclusion. This reality is clearly seen in the most recent available data about the ethnic composition and level of formal schooling of people imprisoned in the Federal District, which reveal that $83.5 \%{ }^{23}$ of these people were black or brown (SISDEPEN 2020); 52\% did not reach high school and only $9.1 \%$ had high school

23 Against 56.2\% in general population (IBGE 2010). 
degrees (INFOPEN 2017). Thus, the phenomenon analyzed by Honneth helps us to understand, in part, the difficulty that these people have in formulating their experiences in terms of more propositional claims and not only through negative feelings.

However, it is certain that the phenomenon he identified, although it is part of the social reality of these citizens, is different to that which we are analyzing in this article. Firstly, the processes of discursive exclusion treated here involve mechanisms specific to prison institutions and not to broader social processes that do not have an a priori association with this system. Our ethnographic material about discursive exclusion in the prison universe reveals that it is not possible to understand this phenomenon without locating it in the specific realm of this institution. In this sense, one of the most marked traits of this discursive exclusion its radicality, which, at its limit, can lead to a situation of complete incommunicability of incarcerated people, as in the case reported by Francisco, in which people injured in the invasions were placed in isolation to prevent their families from seeing their wounds. Thus, the coercive dimension, which is not included in Honneth's formulation about cultural exclusion, is central here to understanding and characterizing these mechanisms. Even symbolic and linguistic suppression in this context is not an effect of a cultural hegemony exercised subtlety and disseminated during an individual's socialization, but effectuated through explicit and violent strategies, such as the barring of entrance of law texts to prisons, which can even lead to a punishment.

\section{Conclusion}

In this article, we sought to demonstrate that institutional processes of discursive exclusion constitute a fundamental aspect of the experiences of disrespect lived in the context of incarceration in the Federal District. It is important to reveal these processes to properly understand how rights violations are interpreted and lived by the interlocutors.

Despite the positive expectations created by the third democratizing wave in Latin America, the redemocratization process in the region was not capable of suppressing structural racism and inequalities and guaranteeing the effectuation of the civil and social rights of its citizens as a whole (O'Donnell 1993; Carvalho 2001). During the 1980 and 1990s, simultaneously to this process, the adoption of neoliberal premises by the elected governments was responsible for attacks on various labor and social rights, with the objective of dismantling the social protection network for local citizens. Allied to this, since the 1990 s we have observed the importance of a criminal policy model in the region, which is characterized by movements and discourses calling for law and order and by a massive broadening of criminalization of non-violent conduct, especially that associated to illegal drug sales in poor regions of urban peripheries (Wacquant, 2012; Zaffaroni, 2001). Wacquant (2012) affirms that this mass incarceration policy has even become the new form of administration of poverty in neoliberal states ${ }^{24}$.

O`Donnell (1993) and Holston (2008) indicate that this situation has represented a challenge to political theory that, as a rule, concentrates its attention on the analysis of political institutions to reflect on processes of consolidation of democracies. Because in many Latin American countries redemocratization guaranteed citizens the right to vote without this implying an effective guarantee of social and civil rights, this formalist approach has not been able to satisfactorily explain the disjunctions and specificities that characterize this process. In this regard, O'Donnell (1993) pertinently indicated that evaluations of the democratic stabilization process should observe other spheres of social life. Holston (2008) has also argued that it is necessary to adopt an analytical model that considers legal, economic, social and cultural aspects that compose that which he classifies as "substantive experience of citizenship".

24 For an analysis of Wacquant's neoliberal thesis of mass incarceration in the Brazilian context, see Dal Santo (2020). 
Anthropology, with its ethnographic focus, has much to contribute to reflections about democratic experience and citizenship in Brazil. By shifting the analysis from the formal dimension of citizenship to the dimension of how rights are lived, conceived, and problematized daily by concrete social groups and actors, we are able to perceive different rearrangements that point to formulations dissonant from those present in conventional political theories. In this way, anthropologists have destabilized approaches that naturalize the liberal model, demonstrating that it is not possible to adequately understand citizenship as a purely legal status that guarantees individuals a set of rights and responsibilities in relation to the state, as indicated by works of Caldeira and Holston (1999), Cardoso (2014a), Cardoso de Oliveira (2011a) and Lazar (2008).

Our fieldwork shows that the prison institution is a context that is particularly representative of these disjunctions that impact on the substantive experience of citizenship for those groups most vulnerable to criminalization and incarceration, as corroborated by other studies about the theme mentioned in this text. It is thus well known that elements concretely characterized as marks of the dictatorial regime (Aarão Reis Filho 2014), such as arbitrary imprisonment, torture, the violation of human rights by the state, the lack of guarantees of fundamental rights for imprisoned people, censorship and incommunicability of citizens under custody of the state remain intact within prisons, and it cannot be affirmed that there was a break in the mode of action of state institutions in this context after redemocratization. Much to the contrary, despite the adoption of formal, national, and international, laws to guarantee fundamental rights to these citizens, what has been seen after the period of political redemocratization is an extension of the penal and police state ${ }^{25}$, generating a situation that is even more grievous in the realm of prison institutions. In this context, processes of discursive exclusion are central elements that allow a complete lack of transparency of the reality of these institutions and the absence of effective social control over them, allowing them to function, in practice, at the margin of the laws that configure the model of a democratic rule of law.

Received: August 6, 2020

Accepted: May 18, 2021

Translated by Jeffrey Hoff

25 The data reveal an 806\% growth in the Brazilian prison population from 1990 to 2017 (Infopen 2017) 


\section{References}

AARÃO REIS FILHO, Daniel. 2014. Ditadura e democracia no Brasil: do golpe de 1964 à Constituição de 1988. Rio de Janeiro: Zahar.

ALVES, Jaime. 2010. "À sombra da morte: juventude negra e violência letal em São Paulo, Rio de Janeiro e Salvador". Bahia Análise \& Dados, 20(4): 563-578.

ANDRADE, Betânia \& GERALDO, Pedro. 2020. "O outro lado da moeda. Uma análise das práticas de negação de direitos das mulheres no cárcere". Revista de Estudos Empíricos em Direito, 7(2): 33-47.

BIONDI, Karina. 2009. Junto e Misturado: imanência e transcendência no PCC. Dissertação de mestrado, Programa de Pós-Graduação em Antropologia Social da Universidade Federal de Santa Catarina.

BOGO, Luiz. 2006. A capitalização do tempo social na prisão. A remição no contexto das lutas de temporalização na pena privativa de liberdade. Tese de doutorado, Programa de Pós-Graduação em Sociologia da Universidade Federal do Rio Grande do Sul.

BRASIL. 2009. Congresso Nacional. Câmara dos Deputados. Relatório da CPI sistema carcerário. Brasília: Edições Câmara. 620 p.

BRASIL. 2020. Mecanismo Nacional de Prevenção e Combate à Tortura. Relatório Bianual (2018 - 2019). COSTA, Adriana R. F.; MELO, Daniel C.; Silva, Luís Gustavo M. (orgs.). 191 p.

CALDEIRA, Tereza. 200o. City of Wall: Crime, segregation, and citizenship. Berkeley-London: University of California Press.

CALDEIRA, Tereza \& HOLSTON, James. 1999. "Democracy and Violence in Brazil”, Comparative Studies in Society and History, 41(4): 691-729.

CARDOSO, Marcus. 2005. Eu finjo que não te vi, você finge que não me vê": uma etnografia sobre a relação entre polícia comunitária, tráfico e população favelada. Dissertação de Mestrado. Programa de Pós-Graduação em Antropologia Social, Universidade de Brasilia, Brasília.

CARDOSO, Marcus. 2012. "Polícia e direitos na visão dos moradores de duas favelas do Rio de Janeiro". Estudos de Sociologia, 17: 491-507.

CARDOSO, Marcus. 2013. "A dimensão simbólica dos conflitos: moradores de favela e polícia”. Anuário Antropológico, 2012(1): 167-190.

CARDOSO, Marcus. 2014a. "Respect, Dignity and Rights: Ethnographic registers about community policing in Rio de Janeiro". Vibrant, 11: 46-74.

CARDOSO, Marcus. 2014b. "Demandas por direitos e a polícia na encruzilhada". Revista Brasileira de Segurança Pública, 8: 154-169.

CARDOSO DE OLIVEIRA, Luís Roberto. 2011a. Direito Legal e Insulto Moral - Dilemas da cidadania no Brasil, Quebec e EUA. Rio de Janeiro: Editora Garamond.

. 2011b. "Prefácio”. In: J. N. Garcia de Araújo, F. Martins; M. Souza (orgs.), Dimensões da violência: conhecimento, subjetividade e sofrimento. São Paulo: Casa dos Psicólogos. pp. 7-11.

CARVALHO, José Murilo. 2001. Cidadania no Brasil: o longo caminho. Rio de Janeiro: Civilização Brasileira.

CNBB. Pastoral Carcerária Nacional. 2018. Tortura em tempos de encarceramento em massa. MALVEZZI FILHO, Paulo César; VALENTE, Rodolfo de Almeida. (orgs.). São Paulo. Available: https://bityli.com/oRNbv.

DAL SANTO, Luiz P. 2020. "Reconsiderando a tese da penalidade neoliberal: inclusão social e encarceramento em massa no Brasil". Rev. Faculdade de Direito, 44: e60817.

FONSECA, Claudia. 2011. "Direito às Origens: Segredo e Desigualdade no Controle de Informações Sobre a Identidade Pessoal”. Revista de Antropologia, 53(2): 493-526.

FÓRUM BRASILEIRO DE SEGURANÇA PÚBLICA. 2019. Anuário Brasileiro de Segurança Pública, 13. São Paulo. FOUCAULT, Michel. 1996. A Ordem do Discurso. São Paulo: Edições Loyola. . 1997. Il Faut Défendre la Société. Paris: Gallimard-Seuil. 
FREIRE, Jussara. 2010. "Agir no regime de desumanização: esboço de um modelo para análise da sociabilidade urbana na cidade do Rio de Janeiro". DILEMAS: Revista de Estudos de Conflito e Controle Social, 3(10): 119-142.

GEERTZ, Clifford. 1998. "O saber local: fatos e leis em uma perspectiva comparativa”. In: O Saber Local: Novos ensaios em antropologia interpretativa. Petrópolis: Ed. Vozes. pp. 249-356.

GOFFMAN, Ervin. 1974. Manicômios, prisões e conventos. São Paulo: Ed. Perspectiva.

HABERMAS, Jürgen. 1970. “On systematically distorted communication”. Inquiry, 13(1-4): 205-218.

HIGA, Gustavo Lucas; ALVAREZ, Marcos César. 2019. “Humanização das prisões e pânicos morais: notas sobre as Serpentes Negras”. Estudos Avançados, 33: 69-9o.

HOLSTON, James. 2008. Insurgent citizenship: Disjunctions of democracy and modernity in Brazil. Princeton: Princeton University Press.

HONNETH, Axel. 2007. Disrespect. The normative foundation of critical theory. Cambridge: Polity.

IBGE. 2010. Censo Demográfico. Available at: https:|/censo2010.ibge.gov.br|.

INFOPEN. 2017. Levantamento nacional de informações penitenciárias. MOURA, Marcos V. (Org.) Brasília: MJSP Departamento Penitenciário Nacional. Available at: https://bityli.com/zL5SO.

KANT DE LIMA, Roberto. 2003. "Direitos Civis, Estado de Direito e 'Cultura Policial': a formação do policial em questão". Revista Brasileira de Ciências Criminais, 11(41): 241-256.

. 2013. "Entre as leis e as normas: Éticas corporativas e práticas profissionais na segurança pública e na Justiça Criminal”. DILEMAS: Revista de Estudos de Conflito e Controle Social, 6(4):549-580.

LAZAR, Sian. 2008. El Alto, rebel city: self and citizenship in Andean Bolivia. Durham and London: Duke University Press.

LEMOS, Carolina Barreto. 2017a. Violência no Cárcere: agressão moral em estabelecimentos prisionais do Distrito Federal. Dilemas: Revista de Estudos de Conflito e Controle Social, 10: 353-377.

. 2017b. Puxando pena: sentidos nativos da pena de prisão em cadeias do Distrito Federal. Tese de Doutorado. Programa de Pós-Graduação em Direito, Universidade de Brasília, Brasilia, DF.

. "Entre direitos, regalias, regras e castigos: sentidos de justiça nas cadeias do Distrito Federal". Revista de Estudos Empíricos em Direito, 5: 136-147.

. 2019b. "Quem são os direitos humanos? Desconsideração e personificação em cadeias do Distrito Federal". Antropolítica, 47: 31-61.

LEMOS, Carolina Barreto; CARDOSO, Marcus. 2020. "Direitos, elo social e reconhecimento". Revista de Estudos Empíricos em Direito, 7: 13-32.

LIMA, Willian da Silva. 2001. Quatrocentos contra um: uma história do comando vermelho. São Paulo: Labortexto Editorial.

MBEMBE, Achille. 2014. Crítica da razão negra. Lisboa: Antígona.

MEDEIROS, Flavia. 2019. "Sobre discursos e práticas da brutalidade policial: um ensaio interseccional e etnográfico”. Revista ABPN, 11: 108-129.

MELO, Juliana. 2016. "Percepções sobre o sistema de justiça criminal brasileiro a partir de narrativas de mulheres inseridas na prisão como mulas de tráfico". Revista Eletrônica da Faculdade de Direito da UFPel, 2: 179-193.

MELO, Juliana G.; RODRIGUES, Raul. 2017. "Notícias de um massacre anunciado e em andamento: o poder de matar e deixar morrer à luz do Massacre no Presídio de Alcaçuz, RN”. Rev. Bras. Segur. Pública, 11(2): 48-62.

MISSE, Michel. 2010. "Crime, sujeito e sujeição criminal: aspectos de uma contribuição analítica sobre a categoria bandido". Lua Nova, 79: 15-38. 
MUNIZ, Jacqueline. 2018. "Reestruturação dos sistemas policiais: alternativas e seus problemas". In: Paulo Teixeira (org.), Agenda de Segurança Cidadã - Por um novo paradigma. $1^{\text {a }}$ ed. Brasília: CEDES/CDI/Edições Camara. pp. 47-56.

NADER, Laura. 1997. Law in Culture and Society. Berkely: University of California Press.

O’DONNELL, Guillermo. 1993. "On the State, democratization and some conceptual problems: A Latin American view with glances at some post-communist countries". World Development, 21(8): 13551369.

SCHRITZMEYER, Ana Lúcia Pastore. 2019. "Un monstrueux pervers sexuel ou deux? Ethnographie d'un procès à la cour d'assises de São Paulo au Brésil”. Brésil(s) - Sciences Humaines et Sociales, 1: 1-27.

SINHORETTO, Jacqueline. 2015. “O número de presos triplicou. Quem está sorrindo?”. Anuário Brasileiro de Segurança Pública, 9: 84-85.

SILVA, Isabella M. 2019. "Letalidade e Superencarceramento: encadeamento de efeitos sociais em discursos e práticas no Sistema Penal Maranhense”. Revista de Políticas Públicas, 23(1): 150-160.

SISDEPEN. 2020. Levantamento Nacional de Informações Penitenciárias. Brasília: MJSP - Departamento Penitenciário Nacional. Disponível em: https://www.gov.br/depen/pt-br/sisdepen.

WACQUANT, Loïc. 2012. "A tempestade global da lei e ordem: sobre punição e neoliberalismo". Rev. Sociol. Polít., 20(41): 7-20.

ZAFFARONI, Eugenio R. 2001. Em busca de penas perdidas. Rio de Janeiro: Editora Revan.

\section{Carolina Barreto Lemos}

Federal University of Lavras, Law School, Lavras/MG, Brazil

https://orcid.org/0000-0002-2571-4961

Email: cbarretolemos@gmail.com

\section{Marcus Cardoso}

Federal Univeristy of Amapá, Graduate Program in Frontier Studies, Macapá/AP, Brazil

https://orcid.org/0000-0002-9109-4510

Email: marcusacardoso@gmail.com 